\title{
A CROSS-SECTIONAL ANALYSIS OF PHYSICAL ACTIVITY, PSYCHOLOGICAL DETERMINANTS AND HEALTH RELATED VARIABLES OF LATVIAN OLDER ADULTS Aivars Kaupuzs*
}

\author{
*Rezekne Higher Education Institution, Personality Socialization Research Institute, Latvia
}

The study aim is to examine the relationships between self-rated physical activity (PA), health related subjective and objective variables and psychological determinants derived from the Transtheoretical and Social Cognitive theories. The study sample includes 359 respondents aged 60 to 75 years. The short form of the International Physical Activity Questionnaire (IPAQ-SF) was used to assess the level of PA. As a subjective measure of health status it was used The Short Form Health Survey (SF-36v2). For objective health determinants were used the Heart Health consulting room cardiovascular risk factors assessment data. Multidimensional Outcome Exercise Expectation Scale (MOEES) data show the beliefs about the benefits of exercise. To detect the involvement in regular PA it was used the Exercise Stages of Change - a short form. The results show that $20.6 \%$ of respondents have "low" PA level, 30.4\% are "moderate" and $49.0 \%$ are "high" physically active. Nevertheless, only $19.7 \%$ exercise regularly more than 6 months and $49.9 \%$ do not even plan to engage regular activities in the next 6 months. MOEES data show that outcome expectations decrease with the age, the same as PA. These results influence a subjective health assessment, because more than half of respondents are rated below the General Population Norm of SF-36v2 survey. Moreover, poor adherence to exercise is closely related to higher cardiovascular illness risk $(\mathrm{p}<0.01)$.

KEYWORDS: elderly, health benefits, physical activity behavior

\section{INTRODUCTION}

The aging of society will bring social and economic implications affecting most nations across Europe and the world. Physical activity (PA) as a low-cost nonpharmacological intervention could be one of the means to prevent frailty and morbidity in older adults. Physical inactivity has both direct and indirect costs to the health of the population. Physical Activity and Health: A Report of the Surgeon General released by the U.S. Centers for Disease Control and Prevention (1996) summarized a large-scale of evidences that physical activity and good health are inextricably linked. The report highlights the growing evidence of the benefits of physical activity for the reduction of coronary heart disease, some cancers, type-2 diabetes, obesity, osteoporosis, and injury including falls in the older adults' population.

As it is noted in World Health Organization Heidelberg Guidelines for Promoting Physical Activity among Older Persons (WHO, 1997) there are various psychological benefits of regular exercise. Regular physical activity can provide immediate benefits such as relaxation, reduces stress or anxiety and enhanced mood state. Physical activity can also have significant long term positive psychological consequences: improvements of general well-being, mental health and cognitive indicators as well as skill acquisition and motor control performance.

The results from 12028 randomly selected men and women aged 20-79 years show that with increasing physical activity, there was a decrease in high level of stress and life dissatisfaction, (odds ratio $(\mathrm{OR})=0.30$ ). The associations were similar for men and women groups. Moderate levels of activity (2-4 hours of walking per week) showed the most significant difference with regard to the level of stress and dissatisfaction in comparison with those who had low level of physical activity. (Schnohr, Kristensen, Prescott, \& 
Scharling, 2005). Another recent study (Taylor-Piliae et al., 2010) of older adults endorse that lower self-reported stress, anxiety, depression, and higher self-reported mental and physical well-being are significantly associated with higher levels of physical activity.

Physical activities both reduce heart disease risk and enhance health related quality of life (HRQOL) that provides "successful aging". Participation in regular physical activity can also improve the quality of life and physical and psychological functions (including depression), facilitate independent living (McAuley \& Elavsky, 2006).

A number of recent studies have suggested a consistent association between physical activity and quality of life in older adults (Netz \& Wu, 2005; Rejeski \& Mihalko, 2001). For example, Shephard (1993) noted that physical activity plays an important role in increasing the HRQOL of the older adult, by improving physiological and psychological function, which helps to maintain personal independence and reduces the demands for short and long term care services. As noted by Fried et al. (2001), insufficient physical activity is considered a primary marker of physical frailty, which predicts subsequent disability.

Cardiovascular diseases (CVD) are the largest cause of death in Europe and account for approximately over 4.35 million deaths. It is nearly a half of all deaths $(49 \%)$ in Europe (Petersen et al., 2005). Risk factors: inactivity, smoking, high blood pressure, high blood cholesterol, overweight, and diabetes greatly increase the chances of developing heart disease.

The large number of the studies clearly shows that people of all ages can enhance their health by including moderate levels of physical activity into their daily routine (Physical Activity Guidelines Advisory Committee Report, 2008). Regular physical activity is important for good physical and mental health, as well as chronic disease prevention and management. Epidemiological surveys have shown that sedentary lifestyles are associated with markedly increased all cause mortality rates (Pate et al., 1995).

Despite the well-documented benefits of physical activity, most of older adults are not sufficiently active and do not engage in regular leisure-time PA (Crombie et al., 2004). Physical activity is a complex healthrelated behavior. Ronda, van Assema, \& Brug (2001) found out that persons who are not aware of their inadequate physical activity level have a less positive intention to increase their level of activity than those who are not physically active. Almost $60 \%$ of the 2608 Dutch adults did not meet the recommended target for health-enhancing physical activity and half of these respondents were in the precontemplation stage.

McAuley et al. (2008) proposed that the relationships between physical activity and quality of life could best be explained from a social cognitive perspective. The social cognitive theory suggests that the control of behavior, or the motivation to engage in any activity, is based on two main constructs. Self-efficacy expectations, defined as a person's beliefs in their capability to perform a course of action to attain a desired outcome, and outcome expectancies, which are beliefs that a certain consequence will be produced by personal action (Bandura, 1997). Outcome expectations have been found as significant psychological determinant associated with physical activity (Keller, Fleury, Gregor-Holt, $\&$ Thompson, 1999). The solution of this problem requires scientific based information about variables that influence a level of physical activity. Information about people's attitude and believes about physical activities is important for complex problem solving. Only scientifically based data of motivating or impeding factors shows opportunities how to use available resources reasonably. There are still incomplete data of these determinants in Latvia population, particularly in older adults.

This study provides the initial data from older adult population and examines the relationships between self-rated PA, health related subjective and objective variables and psychological determinants derived from the 
Transtheoretical and Social Cognitive theories.

\section{METHODS \\ Participants}

The study samples consisted of 359 respondents $60-75$ years old. The mean age \pm $\mathrm{SD}$ of the participants was $67.3 \pm 7.1$ years. 228 were female $(63.5 \%)$ and 131 male $(36.5 \%)$, the proportion of genders and number of samples are representative for population of Latvia at this age group. The subjects were volunteers without mobility limitations who visited the Heart Health consulting rooms across 5 regions of Latvia to assess cardiovascular risks.

\section{Instruments}

\section{Physical Activity}

The short form of the International Physical Activity Questionnaire (IPAQ-SF) (Craig et al., 2003) was used to assess the level of physical activity. The items in IPAQ are structured to provide separate domain-specific scores for walking, moderate-intensity, and vigorous-intensity activity. All questions refer to the previous 7 days. The results were presented as the estimation of energy expenditure in metabolic equivalent-minutes per week (MET-min/week). Based on the self-reported frequency and intensity of the physical activity, respondents can be classified into a "low", "moderate" or "high" level of a physical activity group. Self administered IPAQ-SF questionnaires were cleared and processed in compliance with the "Guidelines for the data processing and analysis of the International Physical Activity Questionnaire (IPAQ)"

(www.ipaq.ki.se/scoring.pdf).

\section{Exercise Stage of Change Evaluation}

The Transtheoretical Model with the core constructs - stages of change - reflecting behavioral intention of health related behavior change. This model describes the change as a process over the time and progresses through five stages: precontemplation (do not have any intention to exercise); contemplation (have intention to start exercise in the next 6 months); preparation (getting ready to start exercise in the next 30 days); action (exercising, but less than 6 months); maintenance (regularly exercise more than 6 months). To detect the involvement in regular PA, it was used Exercise Stages of Change short form (Marcus, Selby, Niaura, \& Rossi, 1992). Exercising was defined as any planned physical activity performed to increase physical fitness. Such activity should be realized 3 to 5 times per week, 20-60 minutes per session. Participants were asked to choose the definition that best describes the habits of exercising.

\section{Outcome Expectations}

According to Social Cognitive theory, human motivation and behavior are affected by outcome expectations. Physical outcome expectations are characterized by beliefs about pleasant physical experiences that might result from being physically active, such as improving strength and cardiovascular fitness. Social expectations reflect beliefs about having more opportunities to be with other persons or potentially improving what others think of you through being physically active. Self-evaluative outcome expectations are related to the degree to which engaging in exercises might enhance one's self-worth and personal well-being (McAuley \& Blissmer, 2000). The Multidimensional Outcome Expectations for Exercise Scale (MOEES) is a 15-item scale with 6 items reflecting physical outcome expectations (e.g. "Exercise will improve my ability to perform daily activities"; "Exercise will aid in weight control"), 4 items assessing social outcome expectations (e.g. "Exercise will improve my social standing"; "Exercise will make me more at ease with people"), and 5 items measuring self-evaluative outcome expectations (e.g. "Exercise will improve my mood"; "Exercise will increase my mental alertness") (Wójcicki, White \& McAuley, 2009). Participants were asked to rate how strongly they agreed with each of these 15 items on a 5-point scale (1-strongly disagree, 2-disagree, 3-neutral, 4-agree, 5-strongly agree). The sum of total and subscales score 
points was divided with a number of items for inter-comparison between subscales.

The questionnaires of Exercise Stages of Change - short form, IPAQ-SF and MOEES were translated and culturally adapted according to international guidelines. Implementation of these instruments included: forward-backward translation, pretesting and cognitive interviewing, and development of final version.

\section{Health Related Quality of Life Assessment}

The Medical Outcomes Study Short Form version 2 (SF-36v2) is widely used as an extensive health related quality of life measurement (Ware, Kosinski, \& Dewey, 2000). The SF-36 contains 36 items measuring 8 dimensions of health and wellbeing. These attributes are combined using a regression equation and standardized to population norms to provide a physical component summary (PCS) and a mental component summary (MCS). This is a reliable and valid measure in community-dwelling elderly. Evidences for a high degree of internal consistency and construct validity were obtained in study of sample of 827 older adults (Lyons \& Perry, 1994). A standardized Latvian version of SF-36v2 was used in this study with the permission of the Medical Outcome Trust.

\section{Health-Related Variables}

The European Society of Cardiology has developed a risk score system (SCORE) using data from 12 European cohort studies covering a wide geographic spread of countries at different levels of cardiovascular risks. SCORE assessment consists of detecting cardiovascular diseases (CVD) risk factors. CVD risk factors assessment is based on untreated level of systolic blood pressure, cholesterol and glucose level, age and smoking status. All measurements were recorded by trained nurses in Heart Health consulting rooms across 5 Latvia regions. SCORE assessment algorithm enables the medical staff to determine the risk of a cardiovascular event occurring over next 10 years (Erglis et al., 2007). Blood pressure was measured by Aneroid Sphygmomanometer device in sitting position. Total cholesterol and glucose level were measured by The Accutrend Plus system as an express blood strip method. Height was measured using a portable stadiometer, and weight was measured using a calibrated portable scale; body mass index (BMI) was calculated from these measures. Waist-to-hip (WHR) ratio is waist circumference divided by hip circumference. Waist circumference was measured around the narrowest point between the coastal margin and the iliac crest. Hip circumference was measured at the level of the widest diameter around the gluteal region. Body measurements were done with light clothing on and without shoes. Smoking status was obtained by self-report.

\section{Data Analysis}

An exploratory analysis was performed using SPSS for Windows14.0 statistical software. All data were analyzed as continuous variables where possible. Standard methods: the mean, median, standard deviation (SD) and $\%$ were employed for descriptive statistics for each variable. Correlations between continuous variables were tested by the use of Pearson's correlation coefficient. To test overall differences between the groups, Chi Square tests were applied and one-way analysis of variance (ANOVA) was used for continuous data.

\section{RESULTS}

The mean and median results of physical activities domains (walking, moderate and vigorous), total physical activity and percentage values of PA level are represented in Table 1. The results of the study show that $20.6 \%$ of the respondents have "low" PA level, $30.4 \%$ are "moderate" and $49.0 \%$ are "high" physically active and average PA for people at this age group is quite high -4387.2 MET-min/week. Nevertheless, it was clearly defined that physical activity declines with age. There were statistically significant $(p<0.05)$ differences between age groups in total PA results and "low" PA level values $\left(\chi^{2}=26.26\right.$, df $\left.=4, p<0.05\right)$. 
Table 1. Mean (median) values for physical activity in metabolic equivalents-minutes per week (MET-min/week) and physical activity level in different age groups

\begin{tabular}{|c|c|c|c|c|c|c|c|}
\hline Age & $\begin{array}{l}\text { Walking } \\
\text { (MET- } \\
\text { min/week) }\end{array}$ & $\begin{array}{l}\text { Moderate } \\
\text { (MET- } \\
\text { min/week) }\end{array}$ & $\begin{array}{l}\text { Vigorous } \\
\text { (MET- } \\
\text { min/week) }\end{array}$ & $\begin{array}{l}\text { Total } \\
\text { (MET- } \\
\text { min/week) }\end{array}$ & $\begin{array}{l}\text { Low } \\
\text { PA level } \\
\text { (<600 MET- } \\
\text { min/week) }\end{array}$ & $\begin{array}{l}\text { Moderate } \\
\text { PA level } \\
\text { (<3000 MET- } \\
\text { min/week) }\end{array}$ & $\begin{array}{l}\text { High } \\
\text { PA level } \\
\text { (>3000 MET- } \\
\text { min/week) }\end{array}$ \\
\hline $\begin{array}{l}60-64 \\
n=125\end{array}$ & $\begin{array}{l}1626.4 \\
(1188)\end{array}$ & $\begin{array}{l}2235.7 \\
(1800)\end{array}$ & $\begin{array}{l}1665.6 \\
(0.0)\end{array}$ & $\begin{array}{l}5527.7 \\
(3672)\end{array}$ & $9.6 \%$ & $31.2 \%$ & $59.2 \%$ \\
\hline $\begin{array}{l}65-69 \\
n=87\end{array}$ & $\begin{array}{l}1788.6 \\
(1188)\end{array}$ & $\begin{array}{l}1956.8 \\
(1440)\end{array}$ & $\begin{array}{l}827.6 \\
(0.0)\end{array}$ & $\begin{array}{l}4573.1 \\
(4053)\end{array}$ & $19.5 \%$ & $23 \%$ & $57.5 \%$ \\
\hline $\begin{array}{l}70-75 \\
n=147\end{array}$ & $\begin{array}{l}1279.5 \\
(693)\end{array}$ & $\begin{array}{l}1420.1 \\
(720)\end{array}$ & $\begin{array}{l}607.9 \\
(0.0)\end{array}$ & $\begin{array}{l}3307.5 \\
(1590)\end{array}$ & $30.6 \%$ & $34 \%$ & $35.4 \%$ \\
\hline $\begin{array}{l}\text { Overall } \\
n=359\end{array}$ & $\begin{array}{l}1523.7 \\
(990)\end{array}$ & $\begin{array}{l}1834.2 \\
(1200)\end{array}$ & $\begin{array}{l}1029.4 \\
(0.0)\end{array}$ & $\begin{array}{l}4387.2 \\
(2820)\end{array}$ & $20.6 \%$ & $30.4 \%$ & $49 \%$ \\
\hline
\end{tabular}

This study has shown no statistically significant difference between genders in PA category level, but there are some peculiarities in total physical activity. As the results show, men are more active than women (Table 2). It is caused by greater amount of time doing vigorous physical activities. Differences in other PA domains (walking and moderate) were not statistically significant $(\mathrm{p}>0.05)$.

Table 2. Mean values for physical activity in metabolic equivalents-minutes per week (MET$\mathrm{min} /$ week) in male $(M)$ and female $(F)$ of different age groups

\begin{tabular}{|c|c|c|c|c|c|c|c|c|c|}
\hline Age & & $\begin{array}{l}\text { Walking } \\
\text { (MET- } \\
\text { min/week) }\end{array}$ & Sig & $\begin{array}{l}\text { Moderate } \\
\text { (MET- } \\
\text { min/week) }\end{array}$ & Sig & $\begin{array}{l}\text { Vigorous } \\
\text { (MET- } \\
\text { min/week) }\end{array}$ & Sig & $\begin{array}{l}\text { Total } \\
\text { (MET- } \\
\text { min/week) }\end{array}$ & Sig \\
\hline $60-64$ & $\begin{array}{l}\mathrm{F} \\
\mathrm{M}\end{array}$ & $\begin{array}{l}1687.7 \\
1537.4\end{array}$ & .553 & $\begin{array}{l}2047.8 \\
2508.2\end{array}$ & .172 & $\begin{array}{l}984.3 \\
2654.1\end{array}$ & $.001 *$ & $\begin{array}{l}4719.9 \\
6699.8\end{array}$ & $.026 *$ \\
\hline $65-69$ & $\begin{array}{l}\mathrm{F} \\
\mathrm{M}\end{array}$ & $\begin{array}{l}1621.9 \\
2105.5 \\
\end{array}$ & .167 & $\begin{array}{l}2026.7 \\
1824.0\end{array}$ & .618 & $\begin{array}{l}442.1 \\
1560.0 \\
\end{array}$ & $.000 *$ & $\begin{array}{l}4090.7 \\
5489.4\end{array}$ & .117 \\
\hline $70-75$ & $\begin{array}{l}\mathrm{F} \\
\mathrm{M}\end{array}$ & $\begin{array}{l}1126.9 \\
1575.4\end{array}$ & .060 & $\begin{array}{l}1229.3 \\
1790.4\end{array}$ & .057 & $\begin{array}{l}420.2 \\
972.0\end{array}$ & .053 & $\begin{array}{l}2776.4 \\
4337.8\end{array}$ & $.024 *$ \\
\hline Overall & $\begin{array}{l}\mathrm{F} \\
\mathrm{M}\end{array}$ & $\begin{array}{l}1432.7 \\
1681.9\end{array}$ & .113 & $\begin{array}{l}1694.3 \\
2077.6\end{array}$ & .053 & $\begin{array}{l}608.8 \\
1761.5\end{array}$ & $.000 *$ & $\begin{array}{l}3735.8 \\
5521.1\end{array}$ & $.000 *$ \\
\hline
\end{tabular}

Note. $* p<0.05$

Although participants mostly reported sufficient physical activity, the results of Exercise Stages of Change questionnaire show that only $19.7 \%$ exercise regularly more than 6 months and $7.24 \%$ of respondents do it less than 6 months. The main problem revealed is that $49.9 \%$ participants do not even plan to engage regular activities and have no intention to change behaviour in the next 6 months. In the contemplation stage there are $19.2 \%$ of respondents and $4.12 \%$ are planning to start exercise in next 30 days. These results reveal that total PA is not related to planned physical activities (exercising). This finding confirms the data from Multidimensional Outcome Expectations for Exercise Scale.

Outcome expectations reflect beliefs that a given behaviour will produce a specific outcome and have also been associated with physical activity (Bandura, 2004). It means that persons with higher positive outcome expectations would be more physically active. Table 3 contains the descriptive statistics for the Multidimensional Outcome Expectations Scale variables. The findings show that beliefs of beneficial outcomes from exercising are declining with age in the same way as physical activity. Differences between age groups are statistically significant $(p<0.05)$ in 
all categories. Participants had more positive physical and self-evaluative beliefs about the exercise and neutral beliefs about the social benefits of exercise in 60-64 age group. But 70-75 years old people mostly do not expect any benefits from exercising and MOEES total value decline up to 2.86 points by Likert's scale that is between „disagree” and „neutral" statement. This instrument is not gender-sensitive and there are no differences between male and female MOEES results.

Table 3. Mean (standard deviation) values for Multidimensional Outcome Expectations for Exercise Scale (MOEES) in different age groups

\begin{tabular}{|c|c|c|c|c|}
\hline \multirow[b]{2}{*}{ Age } & \multicolumn{3}{|c|}{ MOEES subscales } & \multirow{2}{*}{$\begin{array}{c}\text { MOEES } \\
\text { Total }\end{array}$} \\
\hline & Physical & Social & $\begin{array}{c}\text { Self- } \\
\text { evaluative }\end{array}$ & \\
\hline $\begin{array}{l}60-64 \\
n=125\end{array}$ & $3.82(0.71)$ & $3.07(0.86)$ & $3.45(0.78)$ & $3.49(0.69)$ \\
\hline $\begin{array}{l}65-69 \\
n=87\end{array}$ & $3.52(0.91)$ & $2.66(1.07)$ & $3.02(1.01)$ & $3.12(0.89)$ \\
\hline $\begin{array}{l}70-75 \\
n=147\end{array}$ & $3.15(1.01)$ & $2.51(1.06)$ & $2.79(1.03)$ & $2.86(0.96)$ \\
\hline $\begin{array}{l}\begin{array}{l}\text { Overall } \\
\mathrm{n}=359\end{array}\end{array}$ & $3.48(0.93)$ & $2.74(1.03)$ & $3.08(0.99)$ & $3.15(0.89)$ \\
\hline
\end{tabular}

The data of this study show the tendency that physical outcome expectations of the exercise are more meaningful for older adults than potential social and self-evaluative benefits. Physical activity may improve health-related quality of life (HRQOL) by enhancing physical functioning and by influencing psychological well-being. The Short Form Health Survey SF-36v2 provides the subjective information about respondent's health status. As it was expected the mean values of SF-36v2 components are below the optimal health level. The data from questionnaire indicate that $55 \%$ of Latvian population at this age has physical component summary (PCS) below the General Population
Norm. The score below the norm of mental component summary (MCS) is 52\%. The results of the SF-36v2 questionnaire summary components can be analyzed by Norm-based scoring, where 50 is the mean for the general population and 10 is the standard deviation. It means that scores above 50 are better selfevaluation of health than the general population average, while scores below 50 are worse.

Only $13 \%$ of respondents have score above 50 points; most of them were highly physically active (Figure 1). The mean score of PA for this group was 7723.2 \pm 3827.4 MET$\mathrm{min} /$ week that is twice more than average result for group with below 50 point (3884.7 \pm 4268.8 MET-min/week). 


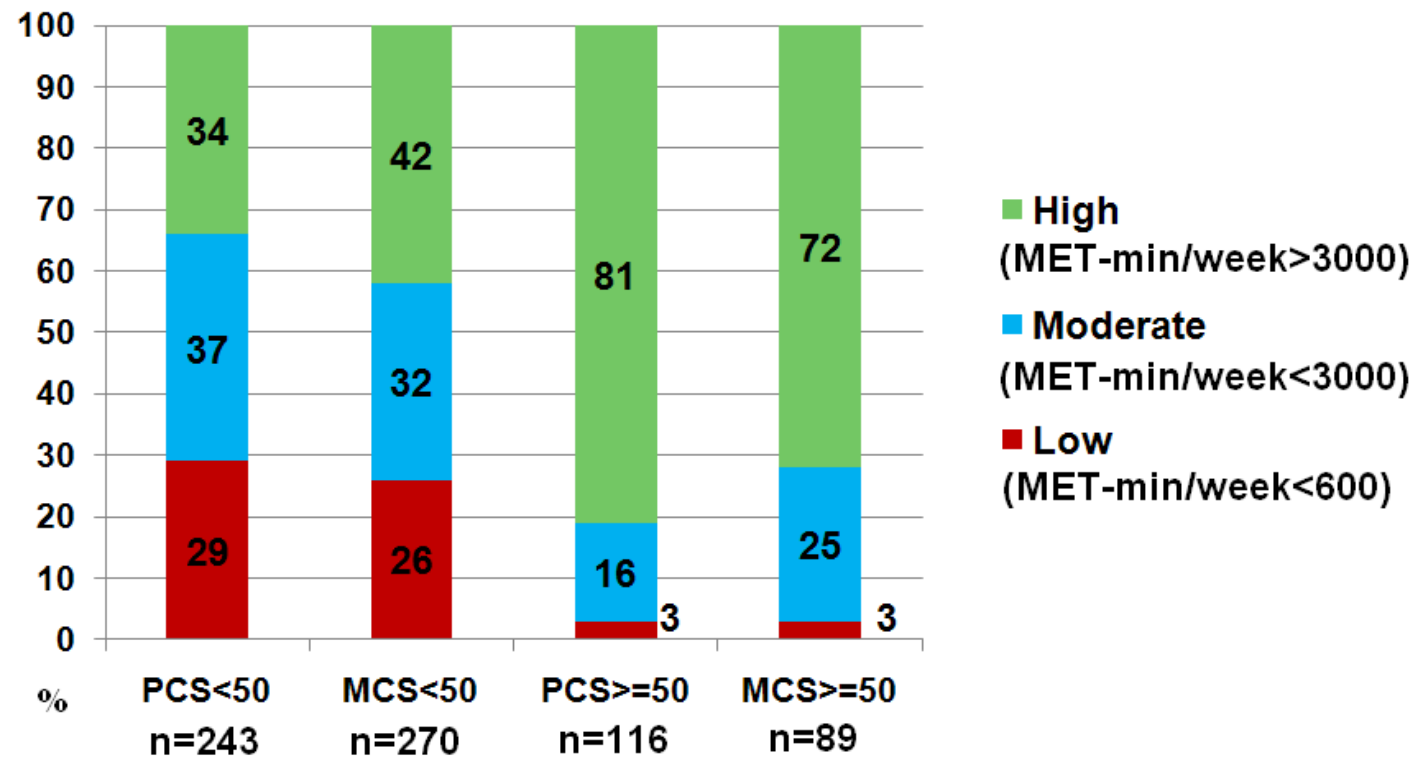

Figure 1 Relationship between physical activity level (IPAQ-SF) and health related quality of life (SF-36v2)

The obtained data suggest that good health self-assessment is directly related to total physical activity. Blair, LaMonte \& Nichaman (2004) noted that recommended minimal physical activity (30 min a day) could be insufficient amount for significant health benefits. This leads to the conclusion that additionally planned exercises are essential for enhancing health.

The cardiovascular diseases risk assessment of the Heart Health consulting rooms provides the objective information about respondent's health status. The obtained data show that
Latvian population at this age has a high risk of a cardiovascular event occurring over next 10 years. $73.5 \%$ of respondents have more than $10 \%$ of SCORE risk (Table 4). The average value is $16 \%$. Also the anthropometrical data (BMI and WHR) of the respondents are on the CVD risk zone. Only $26.2 \%$ of subjects have a healthy BMI score, but $86.1 \%$ have waist-to-hip ratio score which indicate increased health risk. There are also many subjects with hypertension $(64.1 \%)$ and with total cholesterol score above the recommended $5 \mathrm{mmol} / \mathrm{l}$ level (74.9\%).

Table 4. Cardiovascular disease risk variables

\begin{tabular}{lll}
\hline Variable & $\begin{array}{l}\text { Number } \\
\mathrm{N}=359\end{array}$ & $\begin{array}{l}\text { Percentage } \\
\%\end{array}$ \\
\hline Hypertension & 230 & 64.1 \\
\hline Smoking & 46 & 12.8 \\
\hline Total cholestorol level & & \\
\hline$<5.0 \mathrm{mmol} / \mathrm{l}$ & 90 & 25.1 \\
\hline $5-5.9 \mathrm{mmol} / \mathrm{l}$ & 100 & 27.9 \\
\hline $6.0-7.0 \mathrm{mmol} / \mathrm{l}$ & 123 & 34.3 \\
\hline$>7.0 \mathrm{mmol} / \mathrm{l}$ & 46 & 12.8 \\
\hline Glucose level & & \\
\hline $3.3-5.89 \mathrm{mmol} / \mathrm{l}$ & 276 & 76.9 \\
\hline $5.9-6.9 \mathrm{mmol} / \mathrm{l}$ & 47 & 13.1 \\
\hline$>7.0 \mathrm{mmol} / \mathrm{l}$ & 17 & 4.7 \\
\hline
\end{tabular}




\begin{tabular}{lll}
\hline BMI & & \\
\hline $18.5-24.9 \mathrm{~kg} / \mathrm{m}^{2}$ & 94 & 26.2 \\
\hline $25-29.9 \mathrm{~kg} / \mathrm{m}^{2}$ & 159 & 44.3 \\
\hline $30-34.9 \mathrm{~kg} / \mathrm{m}^{2}$ & 75 & 20.9 \\
\hline $35-39.9 \mathrm{~kg} / \mathrm{m}^{2}$ & 20 & 5.6 \\
\hline$>40 \mathrm{~kg} / \mathrm{m}^{2}$ & 11 & 3.1 \\
\hline Waste-hip ratio & & \\
\hline male $>0.95 ;$ female $>0.85$ & 309 & 86.1 \\
\hline SCORE & & \\
\hline $5-10 \%$ & 95 & 26.5 \\
\hline $11-20 \%$ & 184 & 51.2 \\
\hline $21-40 \%$ & 70 & 19.5 \\
\hline$>40 \%$ & 10 & 2.8 \\
\hline
\end{tabular}

Information presented in Figure 2 clearly shows the relationship between physical activity and the assessment of CVD risk variables $(\mathrm{p}<0.01) .56 .8 \%$ of respondents with high physical activity have low (5-10\%) risk of a cardiovascular event occurring over next 10 years, but people with high risk $(>40 \%)$ mostly are inactive. Insufficient physical activity for people with high CVD risk could be mutually as cause as effect. The data from this study do not provide the answer to this problem, but confirm the tendency that more physically active older adults have lower CVD risk.

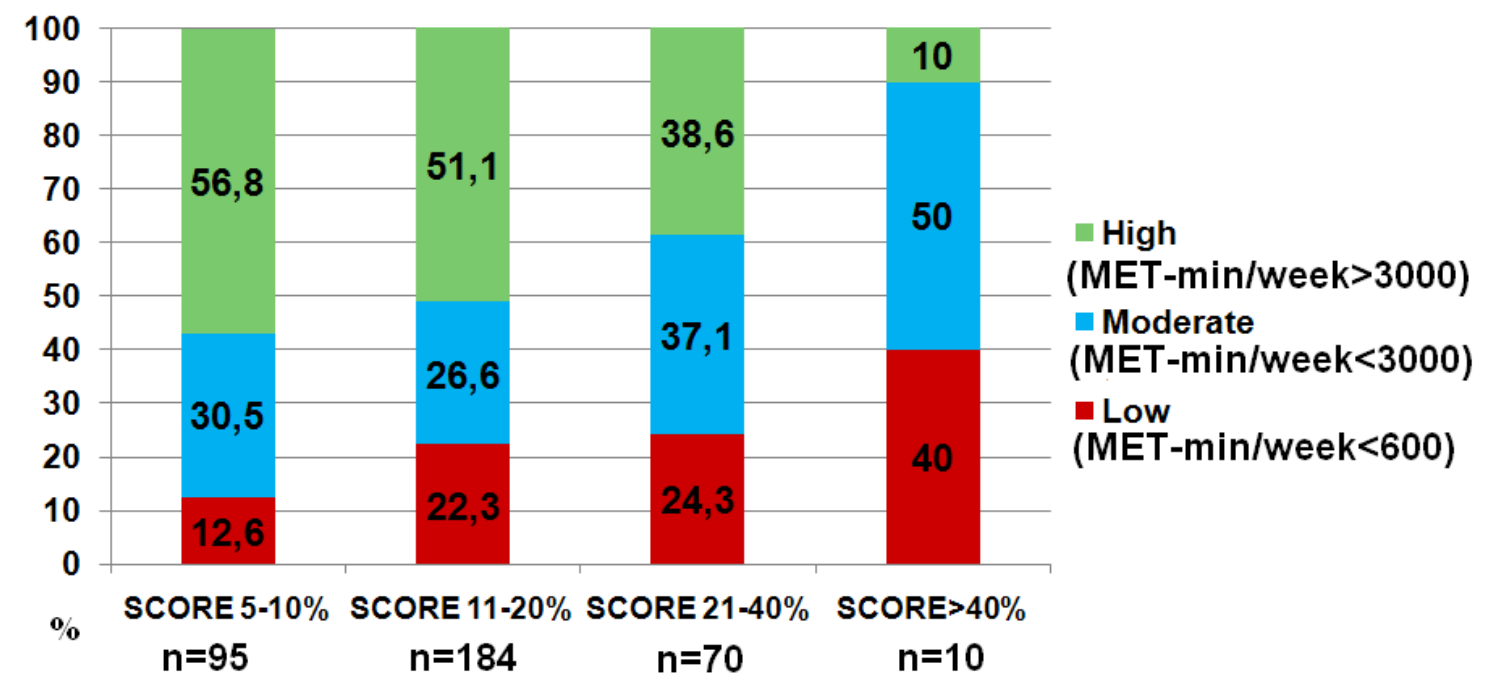

Figure 2 Relationship between the results of physical activity level (IPAQ-SF) and cardiovascular risk assessment

The study results justify the subjective and objective benefits of physical activity for health and well-being; however, there are still problematic questions about PA doseresponse relationship. The data from Figure 2 show that people with high CVD risk (21$40 \%$ ) mostly are moderate or highly physical active. This leads to the assumptions that used thresholds of total PA levels are not connected with health benefits or the concomitant factors (heredity, illness, 
environment etc.) are more substantial determinants of health status. Further research is needed to develop evidence-based cut-off points of required total physical activity for health benefits in the older adult population.

\section{DISCUSSION}

Physical activity guidelines released by the U.S. Department of Health and Human Services (Physical Activity Guidelines Advisory Committee Report, 2008) recommend a minimum of 150 minutes of moderate PA, or 75 minutes of vigorous PA per week, or an equivalent combination of these activities. These guidelines also apply to older adults with additional considerations for special activities for flexibility and balance. If recommendations are not possible to realise due to limiting of chronic conditions, older adults should be as physically active as their abilities allow. The study results show that $79.4 \%$ of Latvian older adults meet the current physical activity guidelines. These findings conflict with the data from other surveys where it is noted that at this age physically active less than one third of population is (Chodzko-Zajko, Sheppard, Senior, Park, Mockenhaupt, \& Bazzarre, 2005; Ferreira, Matsudo, Ribeiro, \& Ramos, 2010). It could be partly explained by potential overestimating of physical activity intensity of respondents. A primary reason for the overestimating of physical activity could be the inability of the respondents to distinguish between light and moderate intensity activities. As an example could be housekeeping or gardening activities, which older adults probably do at a relatively light intensity, but consider that they are being moderately active. Therefore the data from the Exercise Stages of Change questionnaire represent the level of involvement of respondents in health enhancing physical activities. The results show that approximately the half of respondents has no intention to do any additional health enhancing physical activities. The poor adherence to exercise is tightly connected with health related variables. The findings indicate the statistically significant relationship $(\mathrm{p}<0.01)$ between physical activity and subjective and objective health variables. People with higher physical activity level have lower CVD risk and reported a better health-related quality of life. Although the decline in physical activity with age is well known and the study results concur with it this phenomenon is still not well understood. Confidence about the expected benefits of doing exercises is closely related to overall physical activity (Sarkisian, Prohaska, Wong, Hirsch, \& Mangione, 2005). It is also proved by mutual data analysis of MOEES and IPAQ questionnaire results. Analyzing the average results of both questionnaires there was established statistically significant correlation $(\mathrm{r}=0.346$; $\mathrm{p}<0.05$ ). It lets conclude that seniors, who appreciate benefits of exercises higher, are also more active in their daily life.

Statistically significant differences in the results were identified among the groups of people who were in different stages of their physical activity habits. There was traced average correlation between MOEES and average indicators of the scale of the stages in physical activities changes $(r=0.478 ; \mathrm{p}<0.05)$. Evaluating the average results of MOEES at each stage of physical activity changes it has been determined that people, who are not ready to change their habits (precontemplation stage), have the average result of $2.7 \pm 0.81$ points, e.g., they mainly have a negative attitude regarding possible benefits. However, people, who plan to start regular activities, have increased their positive attitude and it has reached $3.4 \pm 0.69$ points. People, who are physically active in their daily life and regularly have physical activities, mainly have a positive attitude towards possible benefits and the average result is $3.8 \pm 0.97$ points.

Although within the study a sufficient level of physical activity was identified among almost a half of the respondents, health-enhancing activities were regularly performed only by every fourth respondent. It is reflected in the main health indicators, which are evaluated as being below the norm. It is traced that people having a lower level of activity have the worst 
objective and subjective health parameters. This study revealed a tendency that along with years physical activity and confidence about its possible benefits reduce. The obtained results let conclude that in the age group from 60 to 75 years confidence about possible benefits of doing exercises is reflected in daily activity and self-evaluation of life quality.

The obtained results let conclude that confidence about possible benefits from being physically active is one of the main factors describing inner motives for regular activities. Influencing person's confidence about the significance of physical activities there is a huge opportunity to change their physical activity habits. The outcome expectations are one of the potential psychological determinants that might affect physical activity in older adults.

\section{PERSPECTIVE}

It is important to acknowledge a number of important limitations that must be considered in the interpretation of these data. The main problem is that the physical activity level was obtained by the questionnaire. The usage of this method might potentially overestimate the results of total physical activity. As in any questionnaire approach, the responses were dependent on respondent's recollection and how attentive the subjects may have been in their responses. The second problem is a sampling of participants as they were community dwelling voluntary persons it was not able to stratified respondents by health characteristics.

Although in the European Union countries a number of population-based studies on physical activity have been conducted (Craig et al., 2003; Oja, Bull, Fogelholm, \& Martin, 2010; Vuori, 2010), in Latvia, there have been some studies on the prevalence of physical activity.

These studies are mostly about overall health assessment and include only some aspects of physical activity. There are no correct data of physical activity in older adult population. Exhaustive information is a prerequisite for a systematic research and knowledge-based policy building. Internationally comparable data on physical activities, determinants of exercise behaviour and health related indicators of older adults are still incomplete in Latvia.

This study has provided initial information for further research and a background for effective intervention program development based on increasing of confidence thereby help to move people through the stage of change.

\section{REFERENCES}

Bandura, A. (2004). Health promotion by social cognitive means. Health Education and Behavior, 31, 143-149.

Bandura, A. (1997). Self efficacy: The exercise of control. New York: W.H. Freeman.

Blair, S., LaMonte, M., \& Nichaman, M. (2004). The evolution of physical activity recommendations: How much is enough? The American Journal of Clinical Nutrition, 79(5), 913S-920S.

Chodzko-Zajko, W.L., Sheppard, J., Senior, J., Park, C., Mockenhaupt, R., \& Bazzarre, T. (2005). The national blueprint for promoting physical activity in the mid-life and older adult population. Quest, 57, 2 11.

Craig, C.L., Marshall, A.L., Sjöström, M., Bauman, A.E., Booth, M.L., Ainsworth, B.E., Pratt, U., Ekelund, U., Yngve, A., Sallis, J.F., \& Oja, P. (2003). International Physical Activity Questionnaire: 12 country reliability and validity. Medicine and Science in Sports and Exercise, 35(8), 1381-1395.

Crombie, I.K., Irvine, L., Williams, B., McGinnis, A.R., Slane, P.W., Alder, E.M., \& McMurdo, M.T. (2004). Why older people do not participate in leisure time physical activity: A survey of activity levels, beliefs and deterrents. Age \& Ageing, 33(3), 287-292.

Erglis, A., Kalvelis, A., Lejnieks, A., Dzerve, V., Latkovskis, G., Mintale, I., Zakke, I., \& Rasa, I. (2007). Kardiovaskulāro slimību (KVS) profilakses vadlīnijas. Latvijas kardiologu biedrība. Rīga, 215. 
Ferreira, M.T., Matsudo, S.M., Ribeiro, M.A., \& Ramos, L.R. (2010). Health-related factors correlate with behavior trends in physical activity level in old age: Longitudinal results from a population in São Paulo, Brazil. BMC Public Health, 10, 690-699.

Fried, L.P., Tangen, C.M., Walston, J., Newman, A.B., Hirsch, C., Gottdiener, J., Seeman, T.,Tracy, R., Kop, W.J., Burke, G., \& McBurnie, M.A. (2001). Frailty in older adults: evidence for a phenotype. J Gerontol A Biol Sci Med Sci, 56:M, 146-156.

Keller, C., Fleury, J., Gregor-Holt, N., \& Thompson, T. (1999). Predictive ability of social cognitive theory in exercise research: An integrated literature review. The Online Journal of Knowledge Synthesis for Nursing, 62.

Lyons, R.A., \& Perry, H.M. (1994). Evidence for the validity of the Short-form 36 questionnaire (SF-36) in an elderly population. Age \& Ageing, 23(3), 182.

Marcus, B.H., Selby, V.C., Niaura, R.S., \& Rossi, J.S. (1992). Self-efficacy and the stages of exercise behavior change. Research Quarterly for Exercise and Sport, 63, 60-66.

McAuley, E., \& Blissmer, B. (2000). Selfefficacy determinants and consequences of physical activity. Exercise and Sport Science Reviews, 28, 85-88.

McAuley, E., \& Elavsky, S. (2006). Physical activity, aging, and quality of life. In W. Zhu \& W. Chodzko-Zajko (Eds.), Measurement issues in aging and physical activity (pp. 57-68) Champaign: Human Kinetics.

McAuley, E., Doerksen, S., Morris, K., Motl, R., Hu, L., Wójcicki, T., \& ... Rosengren, K. (2008). Pathways from physical activity to quality of life in older women. Annals of Behavioral Medicine, 36(1), 13-20

Netz, Y., \& Wu, M. (2005). Physical activity and psychological well-being in advanced age: A meta-analysis of intervention studies. Psychology \& Aging, 20(2), 272284.

Oja, P., Bull, F.C., Fogelholm, M., \& Martin, B.W. (2010). Physical activity recommendations for health: What should Europe do? BMC Public Health, 101-105.

Pate, R.R., Pratt, M., Bair, S.N., Haskell, W.L., Macera, C.A., Bouchard, C., Buchner, D.,Ettinger, W., Heath, G.W., King, A.C., Kriska, A., Leon, A.S., Marcus, B.H., Pollock, M.L., Rippe, J.M., Sallis, J., \& Wilmore, J.H. (1995). Physical activity and public health: A recommendation from the Centers for Disease Control and Prevention and the American College of Sports Medicine. JAMA, 273, 402-407.

Petersen, S., Peto, V., Rayner, M., Leal, J., Luengo-Fernandez, R., \& Gray, A. (2005). European cardiovascular disease statistics. Oxford: British Heart Foundation.

Physical Activity Guidelines Advisory Committee report, 2008. To the Secretary of Health and Human Services. Part A: executive summary. (2009). Nutrition Reviews, 67(2), 114-120.

Rejeski, W.J., \& Mihalko, S.L. (2001). Physical activity and quality of life in older adults. J Gerontol A Biol Sci Med Sci, 56(Spec No 2), 23-35.

Ronda, G., van Assema, P., \& Brug, J. (2001). Stages of change, psychological factors and awareness of physical activity levels in the Netherlands. Health Promotion International, 16(4), 305-314.

Sarkisian, C.A., Prohaska, T.R., Wong, M.D., Hirsch, S., \& Mangione, C.M. (2005). The relationship between expectations for aging and physical activity among older adults.

JGIM: Journal of General Internal Medicine, 20(10), 911-915.

Schnohr, P., Kristensen, T. S., Prescott, E., \& Scharling, H. (2005). Stress and life dissatisfaction are inversely associated with jogging and other types of physical activity inleisure time: The Copenhagen City Heart Study. Scandinavian Journal of Medicine and Science in Sports, 15(2), 107-12.

Shephard, R.J. (1993). Exercise and aging: Extending independence in older adults. Geriatrics, 48, 61-64. 
Taylor-Piliae, R., Fair, J., Haskell, W., Varady, A., Iribarren, C., Hlatky, M., \& ... Fortmann, S. (2010). Validation of the Stanford Brief Activity Survey: Examining psychological factors and physical activity levels in older adults. Journal of Physical Activity \& Health, 7(1), 87-94.

U.S. Department of Health and Human Services. (1996). Physical Activity and Health: A Report of the Surgeon General. Atlanta, GA U.S. Department of Health and Human Services, Centers for Disease Control and Prevention, National Center for Chronic Disease Prevention and Health Promotion.

Vuori, I. (2010). Physical activity and cardiovascular disease prevention in Europe: An update. Kinesiology, 42(1), 515.

Ware, J.E., Kosinski, M., \& Dewey, J.E. (2000). How to score version 2 of the SF$36{ }^{\circledR}$ health survey (standard \& acute forms). Lincoln. R.I, QualityMetric.
Wójcicki, T.R., White, S.M., \& McAuley, E. (2009). Assessing outcome expectations in older adults: The Multidimensional Outcome Expectations for Exercise Scale. Journals of Gerontology Series B: Psychological Sciences \& Social Sciences, 64B(1); 33-40.

World Health Organization (1997). The Heidelberg Guidelines for Promoting Physical Activity Among Older Persons. Journal of Aging and Physical Activity, $5(1), 2-8$.

Guidelines for the data processing and analysis of the International Physical Activity Questionnaire (IPAQ) Retrieved October 5, 2011, from www.ipaq.ki.se/scoring.pdf

Corresponding author's e-mail address: aivars.kaupuzs@inbox.lv

(Abstract)

IPAQ VARIABLE VON ÄLTEREN ERWACHSENEN IN LETTLAND Aivars Kaupuzs*

* Rezekne Higher Education Institution, Personality Socialization Research Institute, Latvia

Es ist das Ziel dieser Studie, das Verhältnis zwischen selbsteingeschätzter körperlicher Aktivität (KA), gesundheitsbezogenen subjektiven und objektiven Variablen und den vom transtheoretischen Modell und der sozial-kognitiven Theorie abgeleiteten psychologischen Bestimmungsgrößen, zu untersuchen. Die Untersuchungsstichprobe umfasst 359 befragte Personen im Alter zwischen 60 und 75 Jahren. Die Kurzform des International Physical Activity Questionnaire (IPAQ-SF) wurde zur Überprüfung des Aktivitätslevels benutzt. Als subjektives Maß des Gesundheitszustandes wurde The Short Form Health Survey (SF-36v2) herangezogen. Als objektive Gesundheitsdeterminanten wurden die Bezugsdaten für die Überprüfung der kardiovaskulären Risikofaktoren zur Herzgesundheit benutzt. Die Ergebnisse der Multidimensional Outcome Exercise Expectation Scale (MOEES) erfassen die Überzeugungen über den Nutzen von Bewegung. Um die Ausübung von regelmäßiger körperlicher Aktivität festzustellen wurde eine Kurzform der Exercise Stages of Change gebraucht. Die Ergebnisse zeigen, dass 20,6 \% der befragten Personen einen „niedrigen“ KA-Level haben, 30,4 \% sind ,moderat" und 49,0 \% „hoch“ körperlich aktiv. Dennoch bewegen sich nur 19,7\% regelmäßig seit mehr als sechs Monate und 49,9\% haben nicht einmal vor sich in den nächsten sechs Monaten regelmäßig körperlich aktiv zu betätigen. Die Daten der MOEES ergeben dass die Erfolgserwartung mit dem Alter abnimmt, genauso wie die KA. Diese Resultate beeinflussen eine subjektive Gesundheitseinschätzung weil mehr als die Hälfte der befragten Personen unter der Norm der Allgemeinbevölkerung des SF-36v2 liegen. Darüber hinaus korreliert 
eine schwache Einhaltungsbereitschaft für Bewegung stark mit einem höherem kardiovaskulärem Krankheitsrisiko ( $\mathrm{p}<0.01)$.

SCHLÜSSELWÖRTER: Ältere, Gesundheitsnutzen, Bewegungsgewohnheiten

\title{
(Аннотацця) \\ МВФА ПЕРЕМЕННЫЕ ПОЖИЛЫХ ЛЮДЕЙ ЛАТВИИ Айварс Каупуз *
}

\begin{abstract}
* Выстее учебное заведение г. Резекне, Научно-исследовательский институт социализации личности, Латвия
\end{abstract}

Целью исследования является изучение взаимосвязи между самооценкой физической активности, субъективных и объективных переменных связанных со здоровьем и психологической определяющей, полученной от транстеоретической и социальной когнитивной теории. В выборку исследования включены 359 респондентов в возрасте от 60 до 75 лет. Для оценки уровня физической активности была использована краткая форма Международного вопросника по физической активности (IPAQ-SF). B качестве субъективной меры состояния здоровья была использована форма краткого опросника здоровья (SF-36v2). Для объективного определения уровня здоровья были использованы данные оценки, полученные в кабинете диагностики сердечнососудистых факторов риска. Результаты показывают, что 20,6\% респондентов имеют "низкий" уровень физической активности, 30,4\% проявляют "умеренный" и 49,0\% имеют "высокий" уровень физической активности. Тем не менее, только 19,7\% регулярно занимались спортом более 6 месяцев и 49,9\% даже не планируют заниматься регулярной деятельностью в течение ближайших 6 месяцев. Данные показывают, что результат ожидания уменьшается с возрастом, так же, как физическая активность. Эти результаты влияют на субъективную оценку здоровья, потому что более половины опрошенных оценили себя ниже общей нормы SF-36v2 обследования. Кроме того, низкое соблюдение правил физической активности тесно связано с увеличением риска сердечно-сосудистых заболеваний ( $<<0,01)$.

КЛЮЧЕВЫЕ СЛОВА: пожилье люди, польза для здоровья, физическая активность

\footnotetext{
(Resumen)

VARIABLES IPAQ ADULTOS MAYORES EN LETONIA Aivars Kaupuzs*

* Rezekne Higher Education Institution, Personality Socialization Research Institute, Latvia

El objetivo del estudio es examinar las relaciones entre la percepción de la actividad física (AF), de salud relacionados con las variables objetivas y subjetivas y los determinantes psicológicos derivados de las teorías cognitivas Transteórica y Social. La muestra del estudio incluye 359 encuestados de entre 60 a 75 años. La forma abreviada del International Physical Activity Questionnaire (IPAQ-SF) se utilizó para evaluar el nivel de PA. Como una medida subjetiva del estado de salud se utilizó el formulario para la encuesta de salud a corto plazo (SF-36v2). Como determinante objetivo de la salud se usó el Heart Health consulting de evaluación de los factores de riesgo cardiovascular. Resultados de la Escala Multidimensionales de la Expectativa de Ejercicio
} 
(MOEES) muestran las creencias sobre los beneficios del ejercicio. Para evaluar la participación en la PA normal se utilizaron las Etapas de Ejercicio del Cambio - en su formato corto. Los resultados muestran que el 20,6\% de los encuestados muestran un "bajo" nivel de PA, el 30,4\% "moderado" y 49,0\% "alto" nivel de actividad física. Sin embargo, sólo el 19,7\% realiza ejercicio con regularidad más de 6 meses y un 49,9\% ni siquiera tiene pensado incorporarse a actividades física de forma regular en los próximos 6 meses. Los datos de MOEES muestran que las expectativas de resultado disminuyen con la edad, lo mismo que PA. Estos resultados influyen sobre la evaluación subjetiva de salud, ya que más de la mitad de los encuestados están clasificados por debajo de la Norma General de Población de la encuesta SF-36v2. Por otra parte, la baja adherencia al ejercicio está estrechamente relacionada con un mayor riesgo de enfermedad cardiovascular $(p<0,01)$.

PALABRAS CLAVE: personas mayores, beneficios para la salud, conductas de actividad fisica

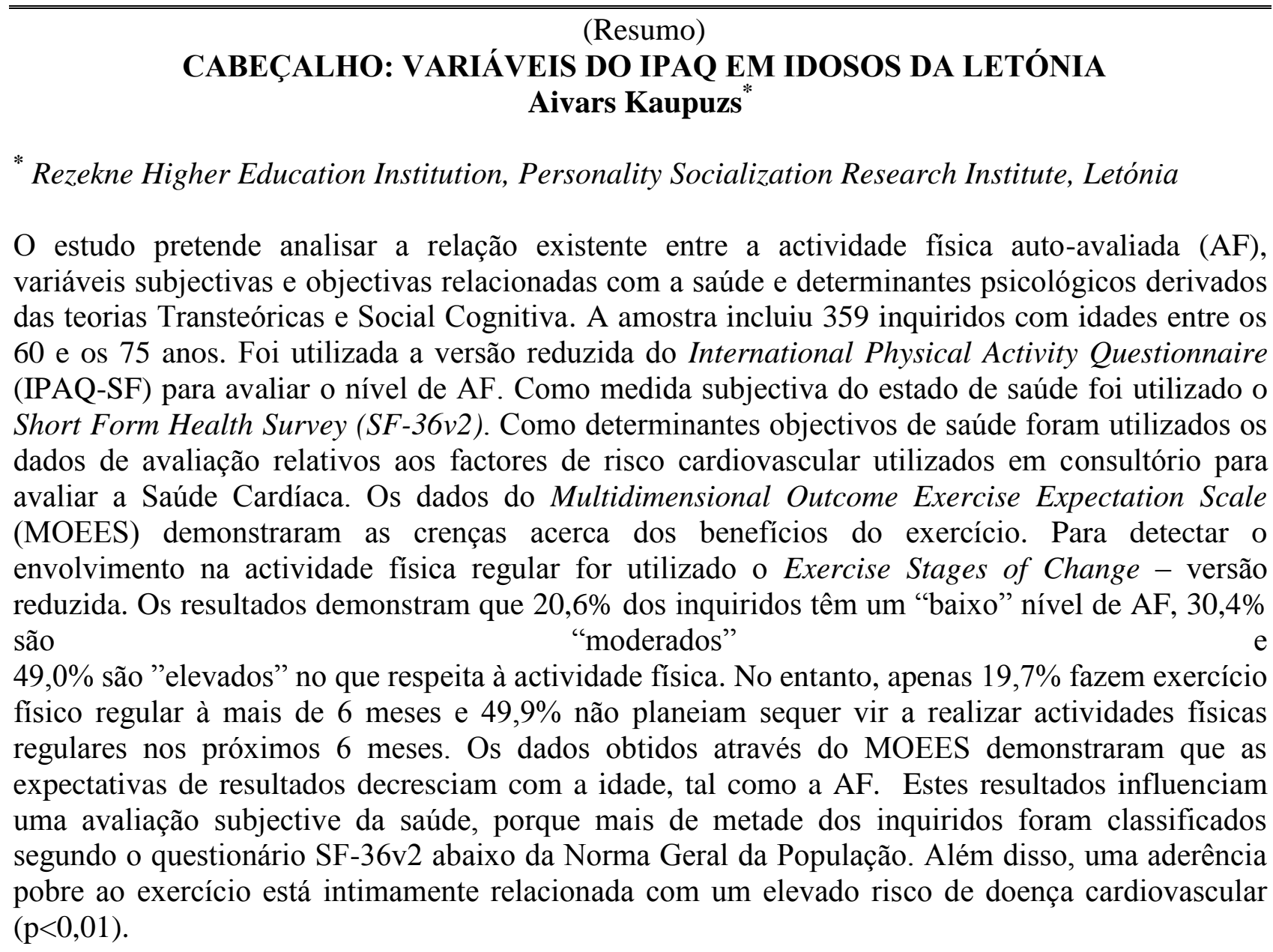

KEYWORDS: idosos, beneficios para a saúde, comportamento direccionado para a actividade física 